16. Национальный состав населения РСФСР. По данным Всесоюзной переписи населения 1989 г. М.: Республиканский информационно-издательский центр, $1990.347 \mathrm{c}$.

17. Краткая социально-демографическая характеристика населения РСФСР (По данным Всесоюзной переписи населения 1989 г. Ч. 1. Численность населения, пол, возраст, национальности, состояние в браке, уровень образования). М.: Республиканский информационно-издательский центр, 1991. 208 с.

18. Сравнительные результаты переписи населения в России, странах СНГ и Балтии [Электронный pecypc] // Земское обозрение. - http://zeminfo.ru/news/ ?id=2126.

19. Численность населения Азербайджана: статистический ежегодник. Баку, 2012. 460 с.

20. Народы Узбекистана. Мордва [Электронный pecypc] // Мой город. - http://mg.uz/publish/doc/ text55669_narody_uzbekistana_mordva.

21. Всесоюзная перепись населения 1989 года. Национальный состав населения по республикам CCСР [Электронный pecypc] // Демоскоп Weekly. http://demoscope.ru/weekly/ssp/sng_nac_89.php?reg=13.

22. Голос эрзи [Электронный ресурс] // http:// goloserzi.ru/etnos/geografiya/geografiya.

23. Никонова Л.И. Область Войска Донского и мордва: к некоторым страницам прошлого и настоящего // Центр и периферия. 2016. № 2. С. 110-115.
24. Никонова Л.И. Мордва-молокане: к истории вопроса // Мат-лы VI всерос. науч.-практ. конф. Рождествено: Ичалковский пед. колледж, 2015. С. 6-11.

25. Центральный государственный архив Республики Мордовия (ЦГА РМ). Ф. Р.-473. Оп. 1. Д. 17. Постановления СНК СССР о плане переселения из республики. Доклад о работе Переселенческого отдела при СНК МАССР за период с 1 октября 1939 г. по 5 мая 1940 г. Планы переселения из районов на 1940 г. и приложения к ним. Заявки на подвижной состав и график отправки переселенческих эшелонов на II и III кварталы 1940 г. на 406 л.

26. ЦГА РМ. Ф. Р.-473. Оп. 1. Д. 38. Дело с анкетами и списками сельхозпереселенцев, отправленных в Кустанайскую, Новосибирскую и Челябинскую области из Краснослободского, Мельцанского, Старосиндровского района. 20 мая -4 июня 1940 г. на 2 л.

27. ЦГА РМ. Ф. Р.-73. Оп. 1. Д. 217. Акты-списки на рабочих, переданных предприятиям, на 347 л.

28. ЦГА РМ. Ф. Р.-473. Оп. 1. Д. 47. Планы переселения из МАССР на 1941 год и документы о их выполнении (постановления, доклады, докладные записки, сведения, переписка). Сведения и отчеты о ходе отбора переселенцев, о количестве отправленных переселенцев. Сведения о количестве вернувшихся переселенцев по районам республики. Географические и экономические характеристики районов и колхозов вселения. 6 января - 17 июня 1941 г. на 565 л.

\title{
DYNAMICS OF THE MORDOVIANS NUMBER IN THE UNION REPUBLICS OF THE USSR
} (C) 2018

\section{Shulgov Evgeny Nikolaevich, postgraduate student of Ethnography and Ethnology Department} Humanities Research Institute (Saransk, Russian Federation)

Abstract. The external parameters of the ecumene include the ethnos number and its dynamics. In the course of the historical process, the Mordovian population on the territory of the near abroad republics (in the Union Republics of the USSR) varied according to natural and climatic, social and economic factors. The history of population migration and the Mordovian population formation in the CIS countries is recorded by the results of the censuses of the Russian Empire and the USSR. The dynamics of the Union republics Mordovians can be traced by censuses of Byelorussia, Kazakhstan, Uzbekistan, Ukraine, etc. Statistical data are confirmed by documents extracted from fund 473 of the Mordovian SSR State Committee on labor and social issues of the Republic of Mordovia Central State Archives. There are folders with various decrees, edicts, plans for interregional migration in the Mordovian ASSR; lists and questionnaires of settlers, acts-lists on workers transferred to enterprises, application forms compiled for resettlers, etc. The purpose of the study is to analyze the types of documentary sources and create a picture of the Mordovian population dynamics on the territory of the near abroad countries (the former Soviet Union Republics). A wide range of documentary sources made it possible to create the picture of the Mordovians migration in Belarus, Kazakhstan, Uzbekistan, Ukraine, and others.

Keywords: number; population dynamics; Mordovia; migration; countries of near abroad; some historical issues; archival data; lists-questionnaires; lists-statements; population censuses; national composition; Belarus; Kazakhstan; Ukraine; Uzbekistan; Mordovian ASSR.

УДК $93(470.55 / 57)$

Статья поступила в редакцию 02.04.2018

\section{РОЛЬ НАУЧНОЙ И ИНЖЕНЕРНО-ТЕХНИЧЕСКОЙ ИНТЕЛЛИГЕНЦИИ ЮЖНОГО УРАЛА В УКРЕПЛЕНИИ ОБОРОННОГО ПОТЕНЦИАЛА СТРАНЫ В ГОДЫ ВЕЛИКОЙ ОТЕЧЕСТВЕННОЙ ВОЙНЫ}

(C) 2018

Кузнецова Юлия Владимировна, кандидат исторических наук, доцент кафедры истории и философии Оренбургский государственный аграрный университет (2. Оренбург, Российская Федераиия)

Аннотация. Значительные территориальные, материальные и людские потери в первые месяцы войны определили приоритетную роль Урала и других восточных районов в укреплении обороны. Поэтому большую роль сыграла научная и инженерно-техническая интеллигенция Южного Урала в укреплении оборонно- 
го потенциала страны в годы Великой Отечественной войны. В статье на основе архивных документов проанализирован вклад научной интеллигенции региона в победу.

Автор рассматривает деятельность специалистов ведущих промышленных предприятий региона в годы войны; выявляет место инженерно-технической интеллигенции в решении проблемы качества советской боевой техники и другой оборонной продукции; отмечает вклад конкретных людей в решение сложных военно-технических задач; показывает творческий поиск технологических и конструкторских коллективов. Сложнейшие задачи в условиях военного времени решали также инженерно-технические работники строительных организаций Южного Урала, выполнявшие приказы Государственного комитета обороны по возведению новых оборонно-промышленных объектов страны.

В статье рассматривается руководство и участие инженерно-технических работников Южного Урала в размещении, монтаже и запуске оборудования эвакуированных военных заводов. Исследователь упоминает и об учебных заведениях, готовивших квалифицированные кадры для промышленности и транспорта, об участии интеллигенции в патриотических движениях по сбору средств в фонд обороны, по подготовке теплых вещей, подарков и продуктовых посылок для Красной Армии.

Ключевые слова: Великая Отечественная война; инженерно-технические работники; Магнитогорский металлургический комбинат; научная интеллигенция; Танкоград; техническая интеллигенция; Челябметаллургстрой; Южный Урал.

Великая Отечественная война потребовала мобилизации не только боевых, но и производительных и интеллектуальных сил страны. Многие представители интеллигенции ушли на фронт, вошли в состав народного ополчения, партизанских формирований. Огромная ответственность по превращению страны в единый боевой лагерь была возложена также на интеллигенцию, работавшую в тылу.

Значительные территориальные, материальные и людские потери в первые месяцы войны определили приоритетную роль Урала и других восточных районов в укреплении обороны. Поэтому особое внимание уделялось привлечению научных и инженернотехнических специалистов восточных регионов к созданию оборонной промышленности.

За 1941-1990 гг. историки опубликовали множество статей, брошюр по истории Урала в годы Великой Отечественной войны. К.И. Клименко одним из первых проанализировал развитие промышленности всего региона [1]. Н.А. Вознесенский привел обобщенные сведения о производстве военной продукции [2].

Значительный вклад в изучении истории промышленного развития Урала внесли А.А. Антуфьев, П.Г. Агарышев, А.З. Безверхний, А.Ф. Васильев, А.В. Митрофанова, Г.Г. Морехина, А.Г. Наумова, М.Т. Солдатенко, А.И. Суханов, В.И. Швыдченко, И.А. Якунцов и другие [3; 4]. В работах затрагивается тема вклада инженерно-технической интеллигенции Южного Урала в укрепление оборонного потенциала страны в 1941-1945 гг. Отдельные сведения по указанной проблеме присутствуют в очерках истории областных партийных организаций [5-9].

Важные стороны деятельности советской интеллигенции различных регионов раскрывает Н.И. Кондакова в книге «Интеллигенция России, 19411945 гг.». Однако сведения по теме исследования практически отсутствуют [10]. Исследование роли производственно-технической интеллигенции в тылу, анализ изменений ее структуры осуществили Т.А. Никитина, В.Д. Павленко, Г.К. Павленко, Л.Н. Синягина, А.В. Федорова, Л.И. Футорянский [11-16].

Автор статьи написал ряд статей и в 2014 г. защитил кандидатскую диссертацию по истории сельской интеллигенции Южного Урала в годы Великой Отечественной войны. В данных работах присутствует фрагментарные сведения по теме статьи [17-23].
Таким образом, следует отметить, что рассматриваемая тема привлекала внимание ученых Урала, однако не получила должного развития.

По приказу ГКО для организации и расширения индустриальной базы на востоке СССР в конце августа - сентябре 1941 года учредили Комиссию по мобилизации на нужды обороны ресурсов Урала, которую возглавил президент Академии наук СССР академик В.Л. Комаров (в апреле 1942 года преобразована в Комиссию по мобилизации на нужды обороны страны Урала, Западной Сибири и Казахстана). К работе в ней привлекали научно-исследовательские учреждения, ученых и преподавателей вузов, инженерно-техническую интеллигенцию, в том числе и южноуральского региона.

За короткий срок, рационально и эффективно используя природные ресурсы, производственные мощности местных и эвакуированных предприятий, предстояло превратить Южный Урал в тыловой оборонный комплекс.

Крупнейшим центром добычи и производства стратегического сырья являлся Магнитогорский металлургический комбинат (ММК) в Челябинской области. В первые военные месяцы горные инженеры и геологи во главе с главным геологом А.Н. Воронковым наладили снабжение Магнитки железной рудой и нерудным сырьем, необходимыми для выплавки высококачественных марок стали, броневой стали и для выполнения других военных заказов. Помощь горному управлению комбината по изысканию новых методов и технологий в разработке, добыче и замене привозного сырья местным, в освоении марганцевых рудников оказывали научный коллектив Магнитогорского горно-металлургического института и комитет ученых помощи фронту, созданный при горкоме партии [24, л. 48].

К осени 1941 года, по предложению главного механика Н.А. Рыженко, главного прокатчика В.П. Кожевникова и других специалистов, на ММК, вопреки утвердившимся к тому времени научно-практическим стандартам и распоряжениям Наркомата черной металлургии, впервые в мировой практике наладили прокат листа броневой стали на блюминге. Благодаря настойчивости и профессионализму инженераметаллурга Г.И. Носова - директора Магнитки, инженерно-технические работники внедрили в производство скоростной метод выплавки спецсталей 
(броневой, снарядной и др.) в большегрузных мартеновских печах [12, с. 99-100; 13, с. 12], не имеющий мировых аналогов. Вместе с магнитогорцами на ММК трудились инженеры-металлурги Днепропетровского, Днепродзержинского, Мариупольского и других эвакуированных в Челябинскую область заводов.

С осени 1941 года при тесном сотрудничестве инженеров-горняков ММК с учеными Магнитогорска и Ленинграда развернулись горные открытые работы по добыче марганца на Уразовском руднике (Учалинский район, Башкирская АССР). В результате в 1942-й и последующие годы большие доменные печи комбината почти бесперебойно выплавляли ферромарганец и марганцевый чугун для оборонной промышленности Урала. Среди южноуральских заводов, производивших боевую технику из магнитогорской спецстали, ведущее место занимал Танкоград - оборонный гигант в составе Челябинского тракторного завода. Буквально за месяц под руководством опытного и талантливого конструктора Л.Е. Сычева инженеры и технологи ЧТЗ провели подготовку к массовому производству танка Т-34, опытные образцы которого успешно прошли испытание на фронте и заслужили похвалу танкистов. 22 июня 1942 года с заводского конвейера сошла первая боевая машина [25, л. 69].

В 1943 году конструкторское бюро Ж.Я. Котина добилось разрешения ГКО на производство тяжелых танков ИС. Созданием этой модели занимались также ленинградские конструкторы Н.Л. Духов и Л.С. Троянов, главный инженер харьковчанин С.Н. Махонин. При активном участии инженерно-технических работников танкоградцам за годы войны удалось создать и запустить в серийное производство 13 моделей танков и САУ (КВ-8, КВ-1С, КВ-85, ИС-1, ИС2 и др.), по многим показателям превосходивших немецкие. Большой вклад в совершенствование танкостроения на Южном Урале внесли украинские специалисты. Только на Кировском заводе Танкограда насчитывалось 1033 инженерно-технических работника, прибывших с харьковских заводов [8, c. 175]. Харьковчанин И.Я. Трашутин, возглавлявший на ЧТЗ конструкторское бюро по моторостроению, изобрел двигатель В-2 для танков Т-34, ИС и самоходных артиллерийских установок.

Сложнейшие задачи в условиях военного времени решали инженерно-технические работники строительных организаций Южного Урала, выполнявшие приказы ГКО по возведению новых обороннопромышленных объектов. При строительстве металлургических заводов широко применялись скоростные методы, разработанные группами инженеровстроителей и инженеров-металлургов под руководством В.Д. Дымшица, Н.Н. Лукашкина, М.А. Шильдкрота. Это позволяло уже в ходе строительных работ вводить в эксплуатацию доменные и мартеновские цеха, в частности, на Бакальском, Магнитогорском, Чусовском металлургических и Челябинском трубопроводном заводах.

Крупнейшие специалисты по бетону и бетонному хозяйству инженеры С.В. Шестоперов и Г.Д. Петров, внедрив в практику метод изготовления железобетонных безнапорных труб с применением виброформ и немедленной распалубки после бетонирования, до- бились экономии большого количества металла Важным техническим новшеством стало использование пропарочной камеры для изготовления железобетонных изделий в зимнее время вне цехов [26, л. 139].

В строительстве жилья по предложению инженеpa С.Е. Шебетовского дефицитные лесоматериалы заменялись стеновыми щитами, изготовленными на специальном станке из хвороста и подручного растительного сырья.

Упрощенный метод покрытия шоссейных дорог дресвой (естественной щебенкой, смешанной с крупнозернистым песком) предложили инженеры-дорожники.

Из отходов деревообрабатывающих производств ИТР Челябметаллургстроя совместно с учеными наладили выпуск гидролизных дрожжей, повышающих калорийность пищевых продуктов.

В предельно сжатые сроки, с августа 1942 г. по февраль 1943 г., инженерно-техническими работниками и рабочим коллективом Челябметаллургстроя во главе с главным инженером В.А. Сапрыкиным запускается первая очередь Челябинского металлургического завода.

Активное участие в строительстве Челябинского металлургического завода принимали военные инженеры А.М. Волынский, М.А. Зарицкий, Н.Б. Лобоцкий, Д.С. Захаров и другие [27, с. 123, 127-129].

Своевременно организовал перестройку работы на военный заказ коллектив инженерно-технических работников Златоустовского металлургического завода. Руководствуясь постановлением СНК от 5 марта 1941 г. «Об изобретательстве и рационализаторских усовершенствованиях», ставшим особенно актуальным в военное время, инженеры завода И.Н. Голиков, П.Е. Бояршинов, А.Н. Корнеенков, известный изобретатель скоростных методов плавки С.И. Малышев, главный инженер И.И. Мурзин и др., разработали новую технологию и перевели завод на производство легированных электросталей в мартеновских печах. Результатами плодотворной совместной деятельности инженеров-металлургов 3МЗ и ученых явились выпуск 170 марок высококачественной стали для авиационной и танковой промышленности, внедрение метода обработки ряда ее марок без проковки на молотах и проката на блюминге слитков спецстали весом до 4,5 т.

Практически единственным в стране в годы войны производителем высокоупорных материалов для черной металлургии стал Саткинский завод «Магнезит». По инициативе главного инженера А.П. Панарина инженерно-технический отдел завода разработал и освоил выпуск хромомагнезитовых изделий повышенной термостойкости, которые использовались не только в СССР, но и его союзниками по антигитлеровской коалиции $[28$, с. $36,56,107,136-$ 137].

Существенный вклад в развитие оборонной промышленности страны в военный период внесла инженерно-техническая и научная интеллигенция Чкаловской области. Со второй половины 1941 г. отчетливо проявилась тенденция численного и качественного ее роста, в первую очередь за счет эвакуированных специалистов. 
В июле 1941 года по решению Совета по эвакуации Чкалов принял 100 сотрудников Наркомата станкостроения СССР. Группа из 9 высококвалифицированных инженеров и техников наркомата, сформированная согласно приказу заместителя Наркома станкостроения И.В. Комзина, проводила обследование промышленных предприятий города с целью оказания им технической помощи по производству военной продукции [14, с. 106].

В суровых осенне-зимних условиях 1941-1942 гг. и в предельно сжатые сроки инженерно-технические работники Оренбуржья руководили и непосредственно участвовали в размещении, монтаже и запуске оборудования эвакуированных в область военных заводов: одесского артиллерийского, киевского авиационного, ленинградских 358-го Наркомата боеприпасов, 174-го танкового, фабрики «Стандарт» и многих других. В отсутствие необходимого количества эвакуированных вместе с заводами инженернотехнических кадров, чкаловским инженерам пришлось осваивать теорию и технологию танкостроения, самолетостроения и другой боевой техники.

Ленинградский авиазавод № 47 в Чкалове специализировался на производстве самолетов УТ-2, ЯК-6 и трехместных лимузинов конструкции А.С. Яковлева, а с сентября 1943 г. - ЩЕ-2 (конструктор А.Я. Щербаков). Инженерно-технический персонал завода, как ведущая производительная сила, обеспечивал технологическую дисциплину и организацию своевременного и качественного производства продукции. Нередко приходилось осваивать рабочие профессии сборщиков, жестянщиков, клепальщиков. Как и на других предприятиях, инженеры-технологи и конструкторы выступали инициаторами и авторами эффективных технологий, рацпредложений, изобретений. Так, инженер Хайт создал прибор для определения марки стали, инженер Халявкин разработал и применил на практике новую технологию производства резцов. С целью соблюдения режима экономии сырья группой инженеров и рабочих завода была внедрена технология заменителей остродефицитных цветных металлов [29, л. 59].

Оперативный стиль работы инженерно-технических работников позволял не останавливать производство или снижать его темпы и в случаях нарушения смежниками планов поставок деталей. Было освоено производство лыж и винтов к самолетам, казеинового клея, пружинных амортизаторов, заклепок $[14$, с. $63-78 ; 15$, с. 34]. Эвакуированный из г. Одессы УССР завод «Автозапчасть» наладил выпуск продукции: минных взрывателей, радиаторов, запасных частей для сельскохозяйственной техники. Завод ежемесячно производил более 270 тыс. минных взрывателей [30, л. 55-56]. Переоборудованный машиностроительный завод им. Куйбышева в г. Бузулуке начал выпускать мины, снаряды, корпуса авиационных бомб [31, с. 135].

Завод «Трактородеталь» им. С.М. Кирова стал изготавливать осколочные мины. Паровозоремонтный завод выпускал снаряды, взрывчатку [32, л. 147].

С полной отдачей, используя свои знания и практический опыт, «ковали Победу» инженеры ЮжноУральского никелевого комбината (г. Орск) во главе с директором А.Н. Малининым и главным инженером А.Н. Мельницким. 15 июня 1942 г. СНК СССР принял постановление о вводе в действие новых цехов на этом заводе [33, л. 20].

По заказу Наркомцветмета инженеры-металлурги комбината разрабатывали и внедряли новые методы получения никеля (Л.М. Бочкарев), плавки файнштейна с повышенным содержанием меди в руде (Ю.Я. Галкин, выпускник Московского института цветных металлов и золота), прогрессивные технологические режимы плавки руды (А.Н. Мельницкий, Ф.М. Бреховских, А.Е. Бердников). Это позволило увеличить проплав руды в 1,6 раза и резко сократить расход дефицитного кокса, уменьшить потери никеля с отвальными шлаками и улучшить условия обслуживания печей [34, л. 210].

С 1941 г. на комбинате началось производство кобальта и сульфата никеля. В течение всей войны возглавлял гидрометаллургический цех инженер C.M. Тепикин, руководивший разработкой сложной технологии кобальто-сульфатного производства. В освоении и усовершенствовании нового процесса участвовала также группа ученых в составе профессора Н.М. Славского и научных сотрудников Г.А. Середы, О.Н. Писаржевской, С.И. Соболя, И.И. Шрамкова.

Совместное сотрудничество с инженерами «Североникеля», прибывшими с группой сопровождения эвакуированного оборудования, позволило в сжатые сроки построить и в 1942 г. ввести в эксплуатацию цех электролиза никеля [10, с. 60-61].

Трудовой долг с чувством глубокой ответственности вместе со своими рабочими коллективами выполняли инженерно-технические специалисты Медногорского медно-серного комбината.

Развитием технологии переработки медно-никелевой руды и других материалов занимался инженер Н.В. Шипулин. Построенная по его проекту установка позволила обеспечить более качественное производство меди и серы, а из отходов - полуфабрикаты для Южно-Уральского никелевого комбината, доводившего их до чистого никеля.

Успешные практические испытания прошел новый метод разделительной плавки руды в ватержакетной печи, разработанный инженерами Глушковым, Бурбой, Малкиным и Аптекарем.

Совершенствование и создание новых технологий и механизмов в топливной промышленности обеспечивали инженеры-горняки Домбаровских угольных шахт, инженеры-нефтяники «Бугурусланнефти» и Орского нефтеперегонного завода им. В.П. Чкалова.

В годы войны в Чкалове, как и в других южноуральских городах, сложился творческий союз научной и инженерно-технической интеллигенции Координационную работу по организации научных изысканий и внедрению их в производство осуществлял научно-технический комитет, созданный при облисполкоме. При содействии комитета инженер Гуревич и профессор Бурче создали установку для получения хлорной извести, доцент медицинского института Олифсон - способ получения дубильного хромового экстракта хромжилина из халиловых хромовых руд, доцент Шершевер и инженер Моргунова - технологию изготовления из местного сырья шлакоизвесткового кирпича.

Тесно сотрудничали научные и инженернотехнические работники в области производства ме- 
дицинской техники и лекарственных препаратов. В ноябре 1941 года в Чкалов прибыл Харьковский завод медицинской аппаратуры, производивший оборудование для госпиталей и других лечебных учреждений, в том числе для офтальмологических клиник. В 1943 году в Орске был смонтирован завод медицинских препаратов и освоено производство инсулина, комналина и др. Результатом совместной деятельности инженеров и ученых стало производство на Орском мясоконсервном комбинате таких лечебных препаратов, как альбумин пищевой, гематоген в таблетках, печеночный экстракт, оварин, пентон. И.Л. Рудницкий в годы войны открыл Гайское и другие месторождения полезных ископаемых. Орские геологи осваивали Орско-Халиловский район [35, л. 89].

За счет эвакуированных вузов на Южном Урале расширилась учебная база по подготовке специалистов с высшим инженерным образованием, в которых остро нуждались оборонные отрасли. В Челябинске разместились Запорожский и Ростовский машиностроительные, Ленинградский электротехнический, Сталинградский механический, Московский автодорожный институты. Дипломированные кадры для металлургической промышленности готовили Магнитогорский горно-металлургический и Днепропетровский металлургический (Магнитогорск). Обучение студентов по ряду технических специальностей осуществлял также Челябинский институт механизации и электрификации сельского хозяйства. В 1943 году в Чкалове открылся филиал Харьковского института инженеров железнодорожного транспорта в составе двух факультетов - механического и факультета движения и грузовой работы.

Формированием технической интеллигенции занималось также более 20 средних учебных заведений, готовивших квалифицированные кадры для промышленности и транспорта.

Приближая победу, инженерно-техническая интеллигенция Южного Урала совместно с рабочими коллективами участвовала в патриотических движениях по сбору средств в фонд обороны, по подготовке теплых вещей, подарков и продуктовых посылок для Красной Армии, в субботниках и воскресниках. Помимо производственных задач главные и ведущие специалисты вели агитационно-пропагандистскую работу, обеспечивали подготовку рабочих кадров, решали бытовые вопросы, проводили занятия по ПВО.

\section{Список литературы:}

1. Клименко К. Уральский промышленный район. М.: Госпланиздат, 1945. 69 с.

2. Вознесенский Н. Военная экономика СССР в период Отечественной войны. М.: Госполитизат, 1947. 192 с.

3. Антуфьев А.А. Уральская промышленность накануне и в годы Великой Отечественной войны. Екатеринбург: Ин-т истории и археологии, 1992. 336 с.

4. Урал - фронту / под ред. А.В. Митрофановой. М.: Экономика, 1985. 344 с.

5. Очерки истории Курганской области / сост. А.М. Курочкин, А.А. Кондрашенков. Челябинск: Юж.-Урал. кн. изд-во, 1968. 476 с.

6. Очерки истории Оренбургской областной организации КПСС / гл. ред. Б.Н. Шебаршов [и др.]. Челябинск: Юж.-Урал. кн. изд-во, 1983. 416 с.
7. Очерки истории Челябинской областной партийной организации. 1917-1967. Челябинск: Юж.Урал. кн. изд-во, 1967. 500 с.

8. Партийная организация Челябинской области в Великой Отечественной войне. Челябинск: Юж.Урал. кн. изд-во, 1967. 669 с.

9. Швыдченко В.И. Оренбургская областная партийная организация в годы Великой Отечественной войны Советского Союза (1941-1945 гг.) // Учен. зап. Оренб. гос. пед. ин-т. Оренбург, 1967. Вып. 25. 187 с.

10. Кондакова Н.И., Маин В.Н. Интеллигенция России. 1941-1945 гг. М.: Луч, 1995. 249 с.

11. Никитина Т.А. О вкладе комбината Южуралникель в победу над фашизмом // Южный Урал - великой Победе: мат-лы регион. науч.-практ. конф., посв. 60-летию Победы над гитлеровской Германией. Оренбург, 2005. С. 59-63.

12. Павленко Г.К., Павленко В.Д. Маршалы трудового фронта: Г.И. Носов и И.М. Зальцман // Урал в военной истории России: традиция и современность. Третьи военно-исторические чтения, посвященные 60-летию Уральского добровольческого танкового корпуса: мат-лы междунар. науч. конф. Екатеринбург: ООО «Издательство УМЦ УПИ», 2005. С. 90-110.

13. Синягина Л.Н. Природные ресурсы Урала на нужды фронту // Война. Культура. Победа: мат-лы Уральского научного форума: в 2 ч. Ч. 1 / под ред. В.Я. Рушанина, Н.Г. Апухтиной, Н.А. Вагановой, Л.П. Кутлиной. Челябинск: Знание, 2005. С. 9-15.

14. Федорова А.В. Оренбург в годы Великой Отечественной войны. Оренбург: Оренб. кн. изд-во, 1995.216 c.

15. Федорова А.В., Босова Т. Оренбургские самолеты - фронту // История Оренбургского края: события, судьбы, реальность: сб. науч. трудов / под общ. ред. А.Г. Ивановой. Оренбург: Изд-во ОГПУ, 1994. C. 31-35.

16. Футорянский Л.И. Вклад интеллигенции Оренбуржья в победу над фашистами // Оренбуржье - Великой Победе. Оренбург, 2005. С. 80-90.

17. Кузнецова Ю.В. Вклад интеллигенции в развитие сельского хозяйства. 1941-1945 гг. (на материалах Чкаловской области) // Великая Отечественная и Вторая мировая войны в контексте XX-XXI веков: в 2 ч. Ч. 2 // Материалы междунар. науч.-практ. конф., посвящ. 65-летию Великой Победы. Челябинск: Изд-во Челяб. гос. пед. ун-та, 2010. С. 76-85.

18. Кузнецова Ю.В. Подготовка кадров сельской интеллигенции Чкаловской области в годы Великой Отечественной войны // Великий подвиг великого народа: межвуз. сб. науч. ст. и материалов, посвящ. 65-летию победы советского народа в Великой Отечественной войне. Самара, 2010. С. 113-119.

19. Кузнецова Ю.В. Сельская интеллигенция Южного Урала в условиях военного времени. 19411945 гг. // Аграрная сфера в контексте российских модернизаций XVIII-XX веков: макро- и микропроцессы: сб. ст. / науч. ред. Г.Е. Корнилов, В.А. Лабузов. Оренбург: Изд-во Регион. центра разв. образ, 2010. C. 386-390.

20. Кузнецова Ю.В. Аграрная наука и сельскохозяйственное производство Южного Урала в условиях военного времени: 1941-1945 гг. // Исторические, философские, политические и юридические науки, культурология и искусствоведение. Вопросы теории 
и практики. Тамбов: Грамота, 2011. № 7 (13): в 3-х ч. Ч. III. C. 106-109.

21. Кузнецова Ю.В. Вклад сельской интеллигенции Южного Урала в обеспечение страны продовольствием (1941-1942 гг.) // Интеллект. Инновации. Инвестиции. 2011. № 2. С. 224-227.

22. Динамика количественного и качественного состава производственно-технической интеллигенции Южного Урала 1941-1945 гг. // Сохранение исторической памяти о Великой Отечественной войне: проблемы и решения: мат-лы всерос. науч.-практ. конф., посвящ. 70-летию Победы в Великой Отечественной войне (1941-1945 гг.): в 2 ч. Ч. II / сост. М.А. Марченко, Г.В. Серебрянская. Нижний Новгород: ООО «ПромоЛинк», 2016. С. 76-82.

23. Кузнецова Ю.В. Сельская интеллигенция Южного Урала в годы Великой Отечественной войны: автореф. ... дис. канд. наук. Оренбург, 2014. 26 с.

24. Объединенный архив Челябинской области (ОГАЧО). Ф.-П. 288. ОП. 6. Д. 247.

\section{THE ROLE OF SCIENTIFIC AND ENGINEERING-TECHNICAL INTELLIGENTSIA OF THE SOUTH URALS IN STRENGTHENING THE COUNTRY'S DEFENSE POTENTIAL IN THE YEARS OF THE GREAT PATRIOTIC WAR}

(C) 2018
25. ОГАЧО. Ф.-П. 288. ОП. 7. Д. 255.

26. ОГАЧО. Ф.-П. 288. ОП. 8. Д. 238.

27. Комаровский А.Н. Записки строителя. М.: Военное издательство министерства обороны СССР, 1972. 264 c.

28. Урал ковал победу: сб.-справочник / сост.: С.Д. Алексеев, Л.М. Евтива, Г.Д. Иргалин [и др.]. Челябинск: Юж.-Урал. кн. изд-во, 1993. 384 с.

29. Центр документации новейшей истории Оренбургской области (ЦДНИОО). Ф. 371. Оп. 5. Д. 223.

30. ЦДНИОО. Ф. 371. Оп. 6. Д. 28.

31. Хроника Оренбургской области: в 3 т. Т. 1. 1934-1990 / под общ. ред. С.М. Муромцевой. Оренбург: Печ. дом «Димур», 2009. 308 с.

32. ЦДНИОО. Ф. 8021. Оп. 1. Д. 408.

33. ЦДНИОО. Ф. 6002. Оп. 1. Д. 446.

34. ЦДНИОО. Ф. 371. Оп. 6. Д. 234.

35. ЦДНИОО. Ф. 371. Оп. 7. Д. 255.

\title{
Kuznetsova Yulia Vladimirovna, candidate of historical sciences,
} associate professor of History and Philosophy Department

Orenburg State Agrarian University (Orenburg, Russian Federation)

\begin{abstract}
Significant territorial, material and human losses in the first months of the war determined the priority role of the Urals and other eastern regions in strengthening defense. Therefore, the scientific and engineering and technical intelligentsia of the Southern Urals played a big role in strengthening the countryэs defense potential during the Great Patriotic War. The author examines the activities of specialists of the leading industrial enterprises of the region during the war years; reveals the place of engineering and technical intelligentsia of the region in solving the problem of Soviet military equipment and other defense products quality. The author notes the contribution of concrete people to the solution of complex military-technical problems; shows creative search for technological and design teams. On the basis of archival documents, the historian analyzed the contribution of the scientific intelligentsia of the region to victory. The most difficult tasks in the conditions of wartime were also performed by the engineers of the construction organizations of the Southern Urals, who carried out the orders of the State Defense Committee to build new defense and industrial facilities of the country. The paper discusses leadership and participation of technical officers of the Southern Urals in the distribution, installation and commissioning of the equipment evacuated war factories. The researcher mentions schools and train skilled personnel for industry and transport, as well as participation of intellectuals in the patriotic movement to raise funds for the defense fund, warm clothes, gifts and food packages for the Red Army.

Keywords: Great Patriotic War; engineering and technical workers; Magnitogorsk Iron and Steel Works; scientific intelligentsia; Tankograd; technical intelligentsia; Chelyabmetallurgstroy; South Ural.
\end{abstract}

УДК 378.18

Статья поступила в редакцию 28.03.2018

\section{ФИЗИЧЕСКАЯ КУЛЬТУРА И СПОРТ В ПОВСЕДНЕВНОСТИ СТУДЕНЧЕСКОЙ МОЛОДЕЖИ В ПЕРВОЕ ПОСЛЕВОЕННОЕ ДЕСЯТИЛЕТИЕ (НА МАТЕРИАЛАХ КУЙБЫШЕВСКОЙ, ПЕНЗЕНСКОЙ, УЛЬЯНОВСКОЙ ОБЛАСТЕЙ)} (C) 2018

\author{
Козловская Галина Ефимовна, доктор исторических наук, профессор, директор \\ Самарский филиал Московского городского педагогического университета \\ (2. Самара, Российская Федерация) \\ Любаева Александра Сергеевна, учитель истории \\ Гимназия «Перспектива» г.о. Самара (2. Самара, Российская Федерация)
}

